\title{
Hard-Rock Coastal Modelling: Past Practice and Future Prospects in a Changing World
}

\author{
Alan S. Trenhaile \\ Department of Earth and Environmental Sciences, University of Windsor, Windsor, ON N9B 3P4, Canada; \\ tren@uwindsor.ca \\ Received: 12 January 2019; Accepted: 30 January 2019; Published: 3 February 2019 \\ check for \\ updates

\begin{abstract}
This paper reviews the history of conceptual and numerical modelling of hard rock coasts (mean annual cliff erosion typically $<1 \mathrm{~mm}$ up to $1 \mathrm{~cm}$ ) and its use in studying coastal evolution in the past and predicting the impact of the changing climate, and especially rising sea level, in the future. Most of the models developed during the last century were concerned with the development and morphology of shore-normal coastal profiles, lacking any sediment cover, in non-tidal environments. Some newer models now consider the plan shape of rock coasts, and models often incorporate elements, such as the tidally controlled expenditure of wave energy within the intertidal zone, beach morphodynamics, weathering, changes in relative sea level, and the role of wave refraction and sediment accumulation. Despite these advances, the lack of field data, combined with the inherent complexity of rock coasts and uncertainty over their age, continue to inhibit attempts to develop more reliable models and to verify their results.
\end{abstract}

Keywords: modelling; rock coast; climate change; Quaternary; rising sea level

\section{Introduction}

Rock coasts serve as: depositories for paleo-environmental evidence; sediment sources for commercially valuable and environmentally sensitive estuaries, marshes, and beaches; tourist destinations, particularly when rocky foreshores are covered by beach sands; and bulwarks that protect increasingly densely populated coastal hinterlands from erosion and flooding [1-3]. Researchers need to acquire a better understanding of rock coast dynamics and evolution, in part to predict and mitigate the effects of rising sea level and possibly greater storminess during this century. Nevertheless, we are still poorly equipped to provide definitive answers to fundamental questions concerning (Figure 1):

a) The nature and relative efficacy of the physical, chemical, and biological processes operating on rock coasts and how they are influenced by the climate, wave regime, tidal range, rock structure and mineralogy, and other factors;

b) Rates of erosion and how they vary spatially within the sub-, inter-, and supratidal zones, and temporally with changes in intertidal morphology;

c) Whether intertidal shore platforms and other elements of rock coasts are essentially contemporary (Holocene), having formed since the sea rose to approximately its present level, or ancient, inherited features formed and modified when sea level permitted coastal processes to expose and reshape the features; and

d) The morphodynamic response of beaches with resistant rock foundations (platform-beaches) to rising sea level, increased storminess, and other manifestations of climate change. 


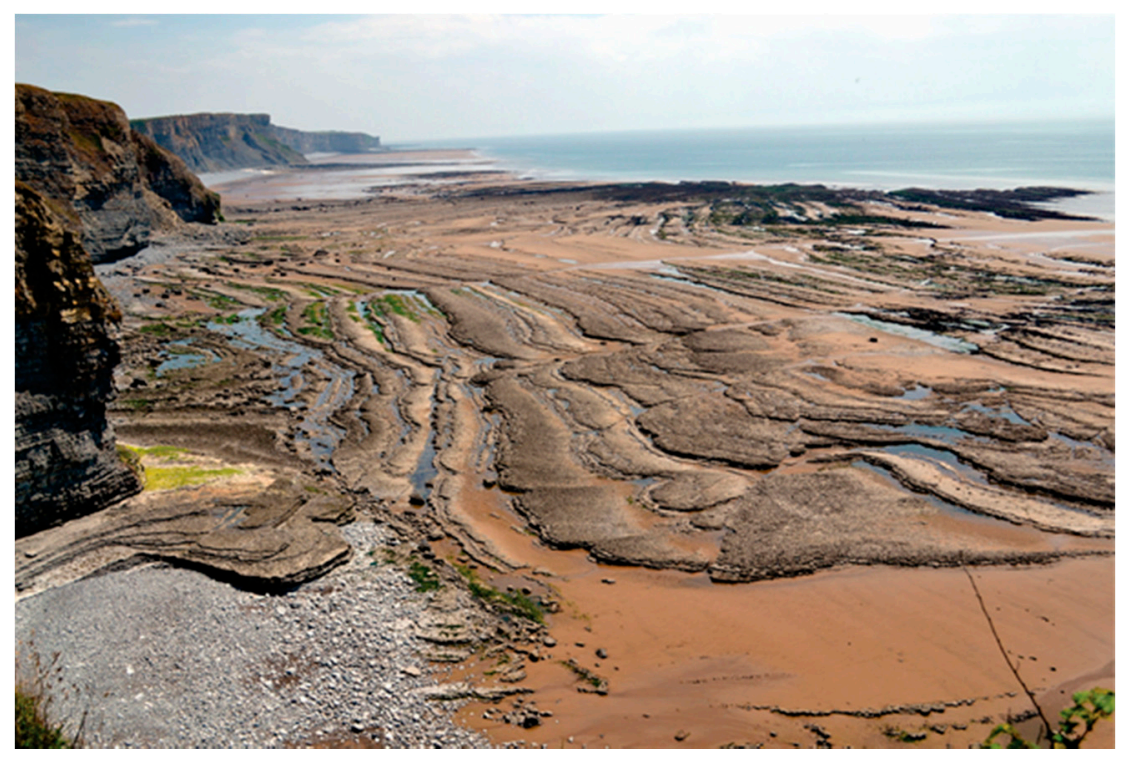

Figure 1. Cliff and intertidal shore platform in Liassic limestones and shales in the Vale of Glamorgan, southern Wales, UK. Pertinent questions might concern the: age of this coast and whether it is partly inherited; nature and efficacy of the formative processes; role of geological conditions; morphodynamics of the pebble and sand platform-beach; and past and potentially future impact of changes in climate and sea level.

Effective management in populated and potentially hazardous coastal regions requires reliable predictive methodologies derived from, and tested against, field data. Slow, generally imperceptible, changes and the lack of datable deposits and suitable dating techniques make it difficult to determine rates and modes of long-term, rock coast development. Modelling is therefore a fundamental and particularly appropriate tool to study changes in rock coasts in the past and to predict likely changes in the future [4,5]. Additionally, modelling can be used to study the relative contribution of different processes suites, including mechanical wave erosion and weathering, and to account for differences in coastal morphology under various geological and environmental conditions.

The purpose of this paper is to review the use of models on rock coasts to: study their development over very long periods in the past and to predict their likely development over much shorter periods in the future; identify limitations inherent in representing complex coastal systems with fairly simple numerical expressions; and suggest possible measures that can be taken to allow better models to be developed. The paper is primarily concerned with process-form modelling of shore platforms and other wave eroded surfaces rather than with mass movement process models or statistical and probabilistic models of coastal cliff retreat [6,7]. Also, despite there being a significant body of literature on soft rock coastal models, this review is restricted to hard rock coasts which, although poorly defined, are generally considered to erode fairly slowly $(<1 \mathrm{~mm}$ up to $1-2 \mathrm{~cm}$, compared with centimetres to metres per year for consolidated clay and other soft rock coasts). The term rock coast is therefore used here to refer to hard rock coasts, unless stated explicitly to the contrary. The distinction between hard and soft rock is arbitrary and often difficult to make, however, particularly where more and less resistant strata alternate in the vertical and horizontal planes.

\section{Rock Coast Models}

Most models have concentrated on the sectional shape of rock coasts rather than the plan form, and there has been little attempt to integrate changes occurring in the horizontal and vertical planes. The dominant feedbacks in the two planes are quite different [8]. Whereas the sectional shape is generally assumed to be controlled by the relationship between rates of wave attenuation and the 
gradient of the bottom, the plan shape is thought to reflect the effect of headland-bay morphology on wave refraction and the protection afforded by accumulating beach material in the bays.

\subsection{Coastal Profiles}

Geologists and other coastal workers were engaged in a debate from about the mid-nineteenth to the early twentieth centuries over the effective maximum depth of marine erosion. A related question, which also had important implications for the development of ideas regarding the long-term evolution of rock coasts, was concerned with the relative roles of marine and subaerial erosion in the formation of wide denudation surfaces [9-12]. The first planation models were conceptual and based on the assumption that marine erosion, by waves or bottom currents, is effective at depths extending from tens to hundreds of metres below sea level. Some workers opined that surfaces developing well below sea level become more gently sloping as they widen through time, whereas others surmised that they attain equilibrium, maintaining constant width and gradient as they migrate landwards [12-15] (Figure 2). By the mid-twentieth century, other qualitative models had introduced the idea that intertidal shore platforms may also attain equilibrium states with constant morphology, due to the effect of platform gradient on rates of wave attenuation and the energy reaching the cliff foot [16-18]. Similarly, Focke [19] proposed that as limestone surf ledges in the southern Caribbean become wider, less spray is able to reach and corrode the cliff, eventually producing an equilibrium state.

Simple numerical models, and in a few cases physical models using plaster and cement blocks in wave tanks and flumes [20-22], had largely superseded conceptual models by the latter part of the twentieth century. These early numerical models were generally concerned with the two-dimensional evolution of subtidal and intertidal profiles. They were structured around a few variables and were based on the assumption that marine erosion is largely accomplished in the submarine zone, or at the water surface in tide-less seas [23-27]. The most effective erosional processes operate in the intertidal rather than in the subtidal zone, however, and at water surfaces that vary in elevation in the short-term, due to tides and storms, and in the long-term, due to changes in sea level and/or elevation of the land.

Mechanical wave erosion is the result of hydraulic quarrying and abrasion. Quarrying dislodges joint blocks and other rock fragments through the impact of waves, surf, and swash on rock surfaces, shock pressures by breaking waves, and air compression in rock cavities. Quarrying is closely associated with the water surface and abrasive efficacy declines rapidly with depth, with the decline in the strength of the wave-generated currents $[1,20,28]$. The most effective wave erosional processes therefore operate at or near to the waterline which, according to most hydraulic models, also experiences the highest wave-generated pressures [1] (pp. 3-19), [2] (pp. 29-37). This conjunction between wave pressures and erosional processes has important implications for modelling, implying that wave erosion is closely related to the tide.

Tidal duration distributions describe the amount or proportion of time (usually a year) that the water surface occupies each intertidal elevation (Figure 3). The distributions suggest that waves operate most often at the neap high and low tidal levels and that wave action is increasingly concentrated at and between these levels as the tidal range decreases. The tidal duration concept is an important component of a wave erosional model that has been used, in a variety of forms, to study the: development of shore platforms under stable sea level conditions [29]; evolution of shore platforms and erosional continental shelves on stable and tectonically active coasts in the Quaternary and Pliocene [30,31]; formation of subaerial and submarine terraces on tectonically mobile coasts [32-34]; and the role of Holocene changes in relative sea level (RSL) on coastal morphology [35,36]. The tidal duration concept has also been used by Matsumoto et al. [37], who developed a numerical model for low tidal range environments. 
A)

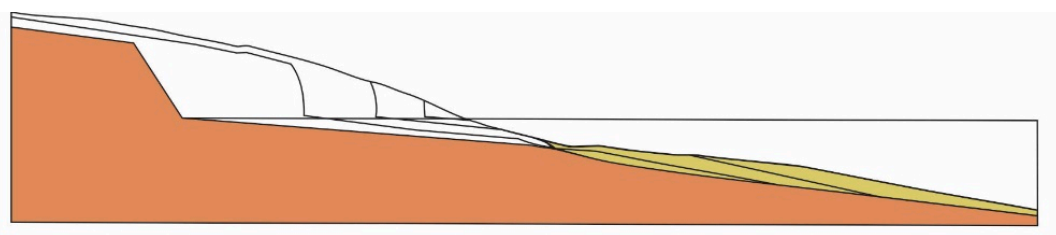

B)

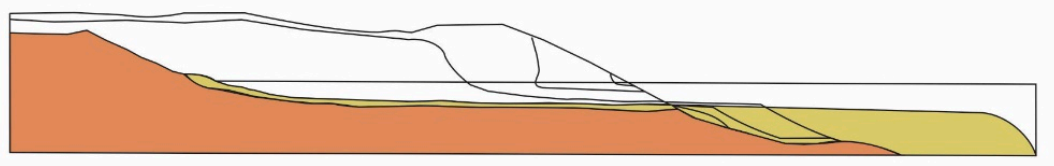

C)

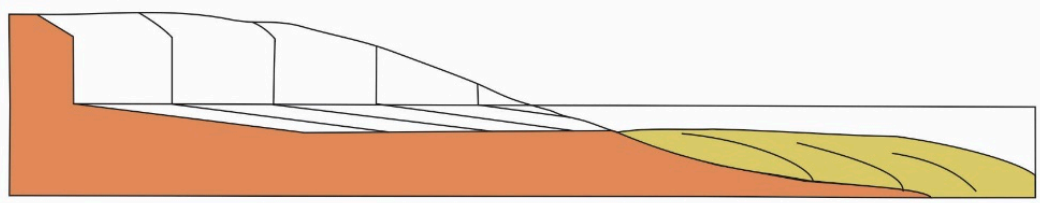

D)
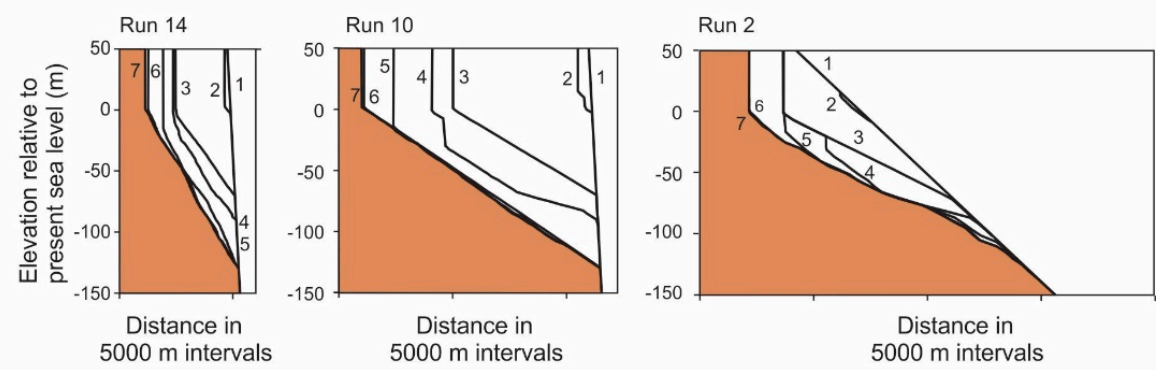

Rock $\square$ Sediment

Figure 2. Models of hard rock coastal evolution with stable sea level according to: (A) Davis [13]; (B) Johnson, [12]; and (C) Challinor [15]. (D) Examples of model runs (run parameters are listed in the original article) examining the evolution of hard rock coastal profiles with changes in sea level on tectonically stable landmasses. Labels 1 to 7 alongside each profile refer to 5.4, 3, 2, 1, 0.5, 0.125, and 0 million years ago, respectively [31].

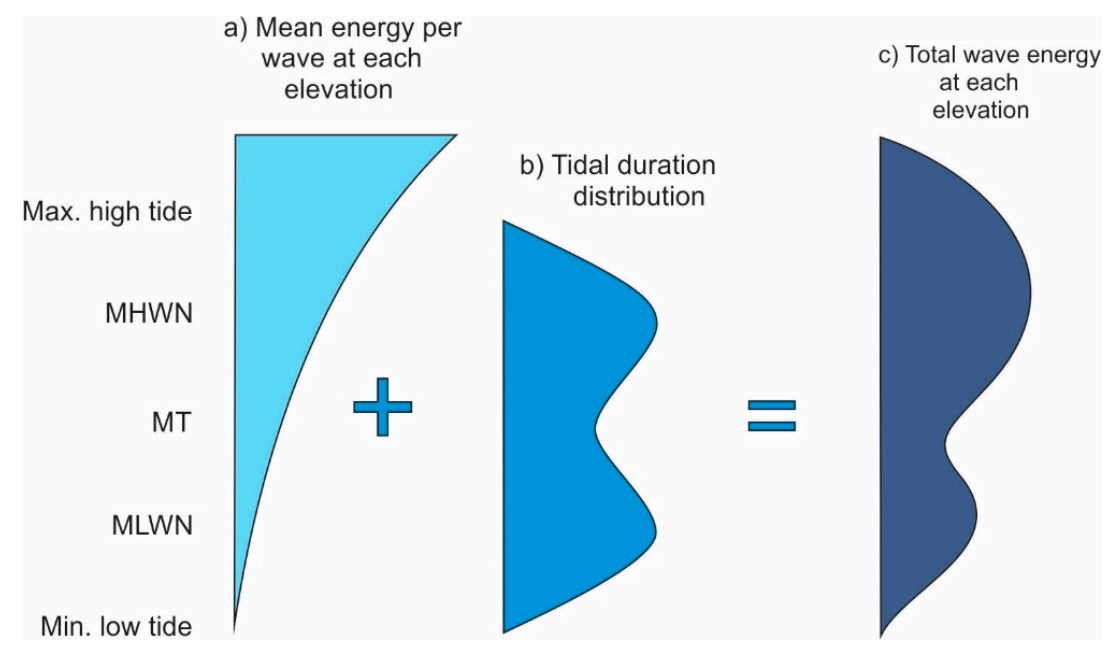

Figure 3. (c) Conjectural representation of wave energy expenditure within the intertidal and supratial zone as a function of: (b) The tidal duration distribution (wave frequency at each elevation); and (a) the effect of tidal modulation and storm surges on individual wave energy and elevation. MHWN, MT, and MLWN refer to mean high water neap, mid-tide, and mean low water neap tidal levels, respectively. 
Rock coasts are often inhospitable depositional environments, due to such factors as slow and often unsuitable fine-grained sediment production, poor sediment retention on steep or high-elevation intertidal surfaces, exposed, wave-swept headlands, and structural and topographic obstructions to longshore sediment transport. Nevertheless, some rock coasts are partially or completely covered in sediment ranging in size from sand to boulders, and most have small deposits trapped in structural depressions or against upstanding beds of resistant rock [38]. There have been only a few attempts to model the morphodynamics of platform-beaches with rock foundations [39,40], or the development of shore platforms, due to the abrasive or protective effect of beach sediments combined with wave quarrying and weathering by tidal wetting and drying [41] (Figure 4).

A)
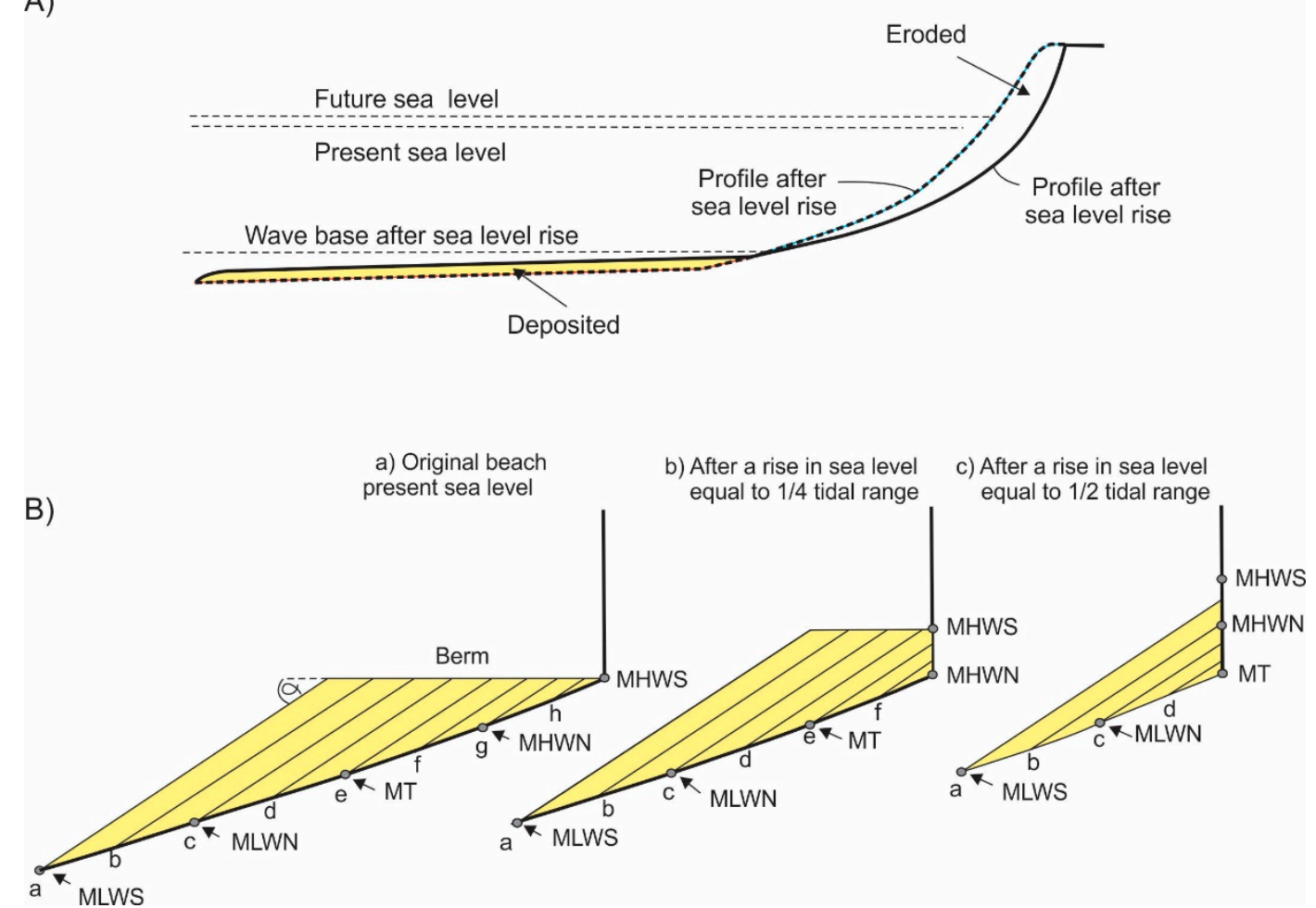

Figure 4. (A) The Bruun Rule suggests that a rise in sea level causes a concordant upward and landward migration of the equilibrium beach profile, with the rise in the water surface being matched by the rise in the nearshore bottom. The sediment needed to raise the floor and maintain the original bottom profile is obtained through erosion on the upper part of the beach. (B) Modelling the morphodynamics and response to changing sea level of beaches with resistant foundations. The model is shown with (a) present sea level and with two $(b, c)$ higher sea levels. The letters below the beach profiles (a to $h$ ), for each of the three sea levels, refer to stages in model calculations to determine if a beach can develop on the resistant foundation under prevailing conditions. Beach extent and morphology change during model runs according to the amount and grain size of the available sediment, the relationship between beachface gradient and the gradient of the resistant foundation, and the beach state, which depends in turn on the prevailing wave conditions. MHWS, MHWN, MT, MLWN, and MLWS refer to mean high water springs, mean high water neap, mid-tide, mean low water neap, and mean low water spring tidal levels, respectively. The shaded (yellow) parts of this figure represent beach sediment and $\alpha$ is the gradient of the beachface. See Trenhaile [40] for a detailed explanation of this model.

It is ironic, given the importance traditionally accorded to weathering in the rock coast literature, and the availability of much better data on surface downwearing (erosion in the vertical plane) than on wave-generated backwearing (erosion in the horizontal plane), that weathering has generally been neglected by rock coast modelers. Nevertheless, a few models have incorporated weathering and 
debris removal in a suite of erosional processes [37,41-44], and others have treated it in isolation to determine whether it can produce shore platforms when acting alone [45-47]. Several semi-quantitative and numerical models have also been developed to consider episodic notch formation and cliff collapse, due to abrasion and weathering, followed by cliff collapse and debris removal [48-52].

\subsection{Coastal Plan-Shape}

Headlands and bays are generally produced by differential erosion of, respectively, more and less resistant rocks (Figure 5). Differences in rock resistance often reflect changes in the type of rock, but they can also be due to, or enhanced by, more subtle variations in rock structure. In addition to inherited inequalities in rock resistance in essentially heterogeneous outcrops, some differences may be due to secondary factors that develop only when a coast has started to develop a crenulated form, including those resulting from changes in the relationship between rock strike and dip and the direction of the refracted waves $[1,53]$. As crenulated coasts develop, wave refraction increasingly concentrates wave energy on the headlands and dissipates it in the bays. Consequently, several conceptual models have suggested that coasts may trend towards an equilibrium plan shape, in which stronger waves erode the more resistant rocks on the headlands at the same rate as weaker waves erode the less resistant rocks in the bays $[12,54,55]$. A corollary of these concepts is that bay depth decreases with the distance between the headlands and increases with the difference in the resistance of the rocks in the headlands and bays.

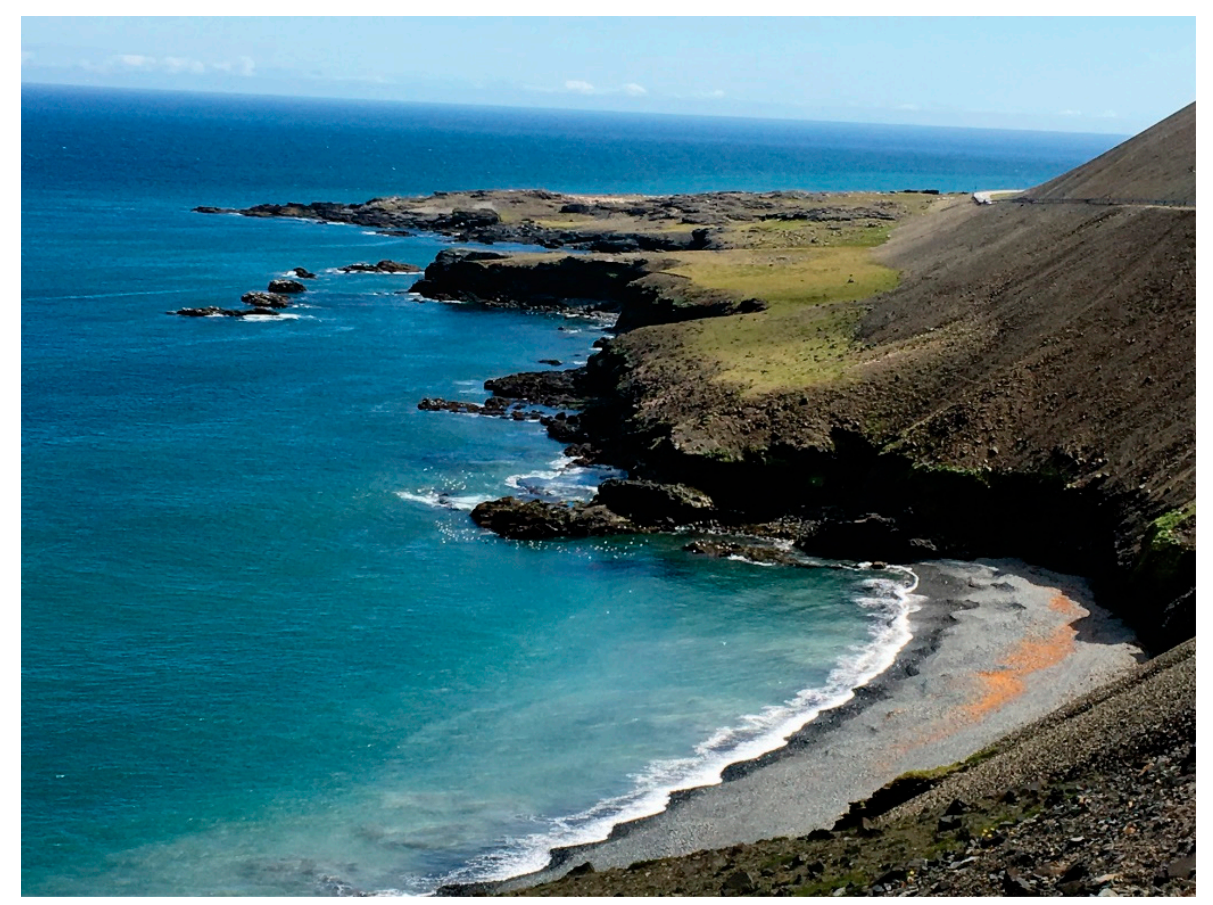

Figure 5. Crenulated coast with a bayhead beach in volcanic lavas, southeastern Iceland.

Plan-shape models also need to consider the complicating effects of: variations in such factors as rock resistance and cliff height, as coasts migrate landwards; the accumulation and redistribution of coarse-grained sediment, especially in bayhead beaches; and Quaternary changes in RSL. The development of crenulated coasts has important implications for the prediction and mitigation of cliff erosion and the impact of rising sea level. Due to a lack of reliable long-term records of episodic cliff recession, however, we do not know whether coasts trend toward equilibrium plan shapes, or if there has been enough time, in any case, for such states to have developed (Figure 6). 
A) Eroded material is fine-grained and transported offshore

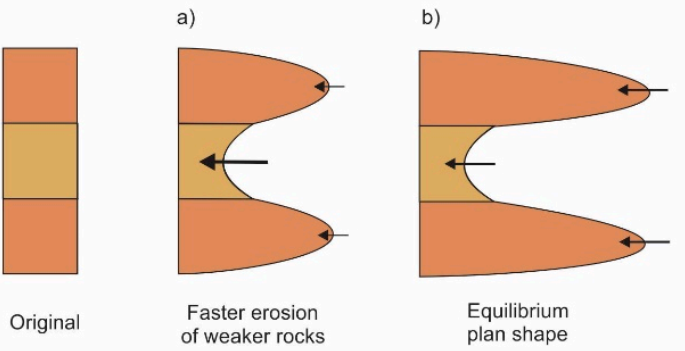

B) Eroded material is coarse-grained (sand to boulders) and accumulates on the coast

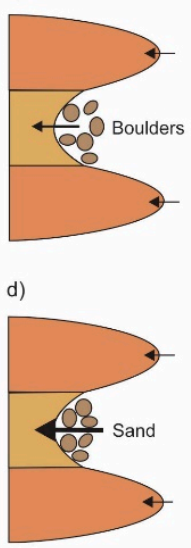

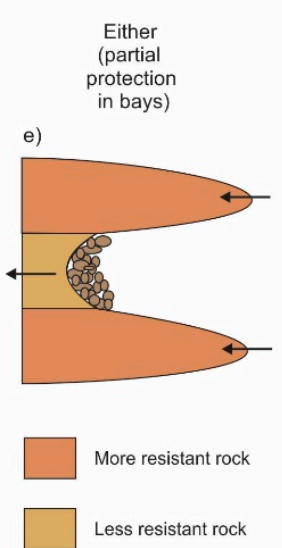

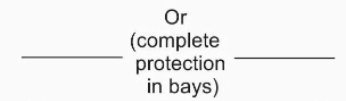

f)

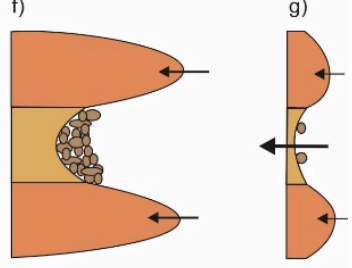

O8O Sediment

$\longleftarrow$ Relative rate of erosion

Figure 6. Possible modes of development of coasts with alongshore variations in rock resistance with fine-grained (A) and coarse-grained (B) sediment. In (A), an equilibrium plan shape develops, due to wave refraction, with stronger waves eroding the harder rocks on the headlands at the same rate as weaker waves erode the less resistant rocks in the bay. In (B), the amount and mobility of the sediment determine whether it plays an abrasional (d) or protective role (c). Equilibrium planform amplitude may develop if some erosion can continue in the bays (e), but complete protection in the bays would cause headland amplitude to decrease (f) and eventually allow sediment to be swept around them, thereby initiating a new cycle of erosion (g) [38].

Limber and colleagues have modelled the development of coastal plan shapes, based on the assumption that erosion is enhanced by the occurrence of small amounts of abrasive material and inhibited by the protective effect of large amounts of sediment [56]. Their model, which is primarily concerned with sand-rich coasts, suggests that longshore variations in beach width can account for the formation of crenulated coasts irrespective of any differences in rock resistance. While the decline in beach volume with increasing distance from river mouths and other source areas could account for broad, plan-shape perturbations, however, beach width along fairly regular coasts is unlikely to vary sufficiently, in quantity or frequency, to trigger the development of more intricate headland-bay sequences at larger scales. Conversely, the accumulation of sediment in pre-existing bays in weaker rock outcrops must play an important role in the subsequent development of crenulated coasts.

Limber and Murray [57] found that the cross-shore amplitude of crenulated coasts is: (a) inversely proportional to the sediment supply and the degree of wave energy convergence on the headlands and divergence in the bays; and (b) directly proportional to the alongshore distance between the headlands and the difference in the strength of the rocks in the headlands and the bays. They noted that the degree of crenulation could diminish in time, due to the erosion of the exposed headlands and the protection afforded by sediment to the back of bays. This would eventually allow sediment to escape alongshore (Figure $6 \mathrm{f}, \mathrm{g}$ ). Related modelling has also suggested that the amount of beach sediment can promote or inhibit the development of stacks off headlands [58]. 
Differences in cliff height are essentially irrelevant in fine-grained rocks that produce clays and other materials that are carried offshore in suspension, but it can be important where rocks break down into coarse grains and rock fragments that accumulate at the cliff foot, thereby helping to protect it from wave erosion [16,59]. In such cases, the height of a cliff partly determines the amount of debris that is produced in an erosional event, and the time required to remove it. The effect of variations in cliff height along crenulated coasts may be superimposed upon the effects of wave refraction and differences in rock resistance, or it might also initiate crenulated forms independently in essentially homogeneous rock outcrops. This could occur because of differences in cliff height, and consequently in rates of recession, between the low cliffs around the mouths of drowned river valleys and the higher cliffs cut into the adjacent watersheds.

\section{Changes in Relative Sea Level}

The long-term evolution of rock coasts has been driven, in part, by Quaternary changes in sea level, and also, in many areas, by tectonic and glacio-isostatic changes in the elevation of the land. Changes in RSL caused intertidal zones and their associated erosional processes, to migrate landwards and seawards, producing wide continental and island shelves, contemporary shore platforms, and elevated marine terraces. Early attempts to model the evolution of rock coasts with changes in RSL, including the quantitative models of Scheidegger [24,60] and the qualitative approach of King [61], were concerned with their response to hypothetical and simplistic representations of steadily rising and falling sea level. Later modellers were able to adopt more realistic representations of sea level change incorporating deep-sea isotopic and other data on sea level changes during the Quaternary.

Sunamura [27] modelled the development of continental shelves, albeit in a non-tidal sea, during the Holocene transgression, producing a convex upward profile that was asymptotic to present sea level. A much wider range of profiles was created in subsequent models that examined the effect of a variety of Holocene relative sea-level curves characteristic of different glaciated and non-glaciated environments [35,62]. The results suggested that the fall in sea level from its mid-Holocene maximum, 1 to $2 \mathrm{~m}$ above its present level, promoted the formation of subhorizontal platforms in Australasia and over much of the Southern Hemisphere, whereas an asymptotic rise in sea level over much of the Northern Hemisphere was more conducive to the development of sloping platforms [35].

Modellers have also considered rock coast evolution over much longer periods of time. Trenhaile (1989) used an earlier model [53] to study the development of continental shelves and wide, subaerial terraces over five glacial-interglacial cycles [49]. In addition to Quaternary changes in sea level, Cinque et al. [63] and Anderson et al. [64] explored the effect of tectonic uplift on the formation of marine terraces. Trenhaile's [29] wave erosional model has been particularly widely applied to study the: effect of high sea levels in marine isotopic stages (MIS) 5 and 7 [65]; Quaternary evolution of shore platforms and continental and insular volcanic island shelves [30,31,33,34]; and the formation of subaerial and submarine terraces during the Quaternary on tectonically mobile coasts [32]. Using a stylized representation of sea level oscillations during the Quaternary, Trenhaile [30] found that falling sea level at the onset and rising sea level at the end of glacial stages truncates and over-steepens intertidal shore platforms. Erosion during the ensuing interglacials, largely at the high tidal level, then modifies the platforms and restores them to a state of quasi-equilibrium with a gradient that is related, in part, to the tidal range. Trenhaile [31] updated this earlier study, using more realistic, and consequently more variable, sea level data to model the development of stable and tectonically active rock coasts over the last 5.4 million years (Figure 2). Among the conclusions were:

a) Some older subaerial terraces (above present sea level), especially on steeply sloping, slowly rising landmasses, were eroded or completely eliminated by the development of younger terraces at lower elevations.

b) Submarine terraces (below present sea level) were modified by erosion during subsequent periods of rising and falling sea level and are best preserved on rapidly subsiding landmasses where they were quickly carried below, and therefore protected from, later glacial stage sea levels. 
c) Prominent terraces formed during glacial, low sea level periods can alternate with those formed during interglacial, high sea level periods in the submarine and subaerial zones of rapidly rising or subsiding landmasses.

d) The larger sea level oscillations of the mid- to late Quaternary were more conducive to erosion than the smaller oscillations in the Pliocene and early Quaternary.

Most models concerned with the effect of sea level rise in the future have been directed at soft rock cliffs which, due to higher rates of erosion, generally pose a greater threat to human lives and activities than hard rock coasts. Nevertheless, several models have considered the impact on hard rock coasts. Trenhaile [66] produced a series of predictive equations that related rates of cliff recession during the present and last centuries. His model suggested that whereas rising sea level will promote faster rates of cliff recession in the future, the effect of increasing storminess may be less important. Young et al. [67] modified the Bruun Rule [68] to model the effect of rising sea level on the Californian coast. This model was based on the premise that the erosion of cliffed coasts fronted by sandy beaches is controlled, in part, by the local sand balance, and consequently by the amount of abrasion or protection that it affords [56,57]. Limber et al. [69] also modelled the effects of rising sea level on the coast of southern California and concluded that erosion rates could more than double with a rise in sea level of 1.5 to $2 \mathrm{~m}$ by the end of this century.

Several models have considered the effect of sea level rise on platform-beaches. In Tarborda and Ribeiro's [70] model, beach sand volume and profile shape remain constant as sea level rises, whereas in Trenhaile's [40] model, the response of platform-beaches to rising sea level varies according to the profile shape and gradient of the rock foundation, the amount and grain size of the sediment, and prevailing wave conditions (Figure 7).

\section{Equilibrium}

Most models have suggested that, under stable sea level conditions, mechanical wave erosion produces surfaces which attain states of static equilibrium with no subsequent change in profile morphology [23,24,26,27,29,53,71,72]. Modelling under oscillating sea level conditions, representing the period from the Pliocene to the present time, also indicated that wave erosion tended to decline through time on stable landmasses, although there were perturbations, due to differences in the amplitude and other parameters of each sea level oscillation $[30,31]$. These differences triggered erosional modifications to the profiles, ranging from a few metres to several tens of metres over the last few thousand years. Despite these adjustments, the general shape of the profiles, extending from the present high tidal level to a depth of about $-130 \mathrm{~m}$ (the lowest sea level in the record), was maintained over the latter part of the middle and late Quaternary (Figure 2).

Static equilibrium occurs in hard rock models when bottom gradients decrease to the point where the maximum stresses generated by the attenuated waves are lower than the threshold for rock breakdown. This implies that rock resistance thresholds are constant through time, despite the effect of such factors as: weathering; the removal of resistant strata that protect or support less resistant rocks; and possibly the accumulating impact of repeated water hammer and air compression in joints. Although wave erosion could be reactivated periodically, due to these factors, intertidal gradients would eventually become so low that wave stresses were permanently below the thresholds for rock erosion. Nevertheless, some erosion could still take place through weathering and removal of fine-grained debris by weak gravity and infragravity waves. This conclusion for sloping intertidal shore platforms in areas with moderate to high tidal range, supports the hypothesis put forth earlier by Dickson et al. [73] for subhorizontal shore platforms in low tidal range environments. It emphasizes the need for weathering to be included in evolutionary models, and implies that erosional thresholds should be represented by time-dependent variables $[37,47]$ rather than by constant values. 
a) linear $3^{\circ}$ foundation, $50 \mathrm{~m}^{2}$ coarse sand,

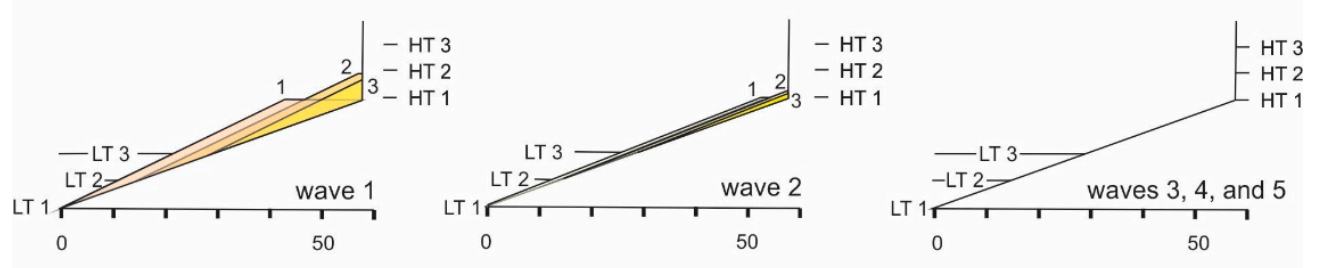

b) linear $3^{\circ}$ foundation, $50 \mathrm{~m}^{2}$ pebble

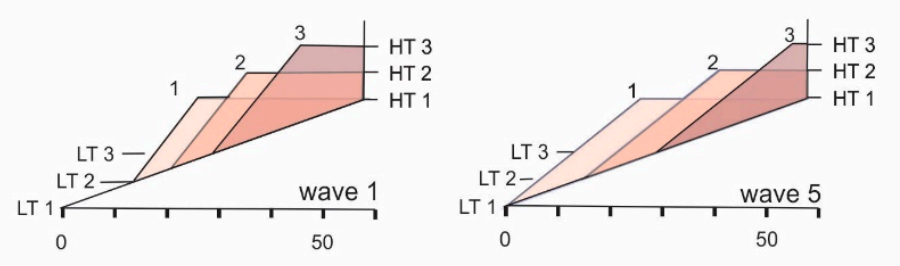

c) linear $2^{\circ}$ foundation, $6.25 \mathrm{~m}^{2}$ pebble, $6.25 \mathrm{~m}^{2}$ fine sand, wave 1

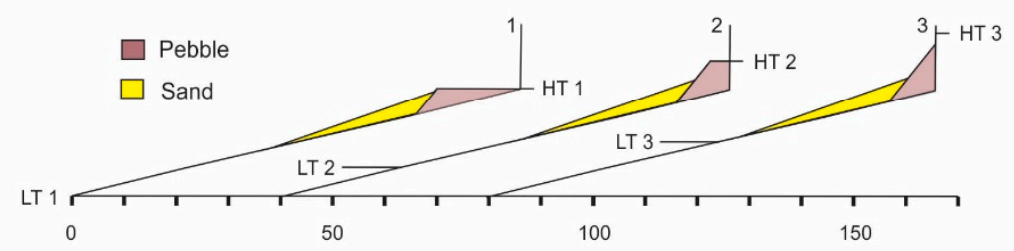

d) concave foundation (1, 2, 3, $4^{\circ}$ from $\mathrm{LT}$ to $\mathrm{HT}$ ), $2 \mathrm{~m}^{2}$ pebble, $2 \mathrm{~m}^{2}$ fine sand, wave 5

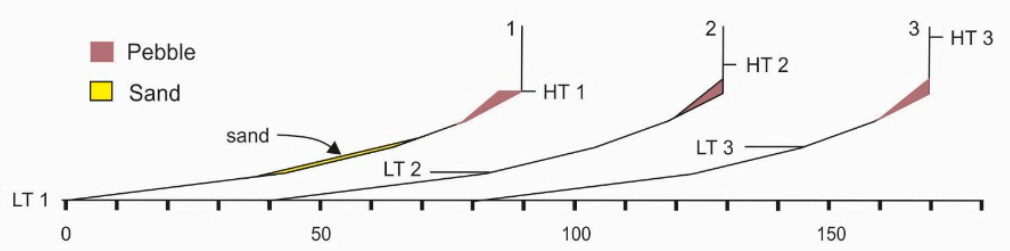

e) convex foundation (2, 3, 2, $1^{\circ}$ from $\mathrm{LT}$ to $\mathrm{HT}$ ), $21 \mathrm{~m}^{2}$ pebble, $1.5 \mathrm{~m}^{2}$ fine sand, wave 3

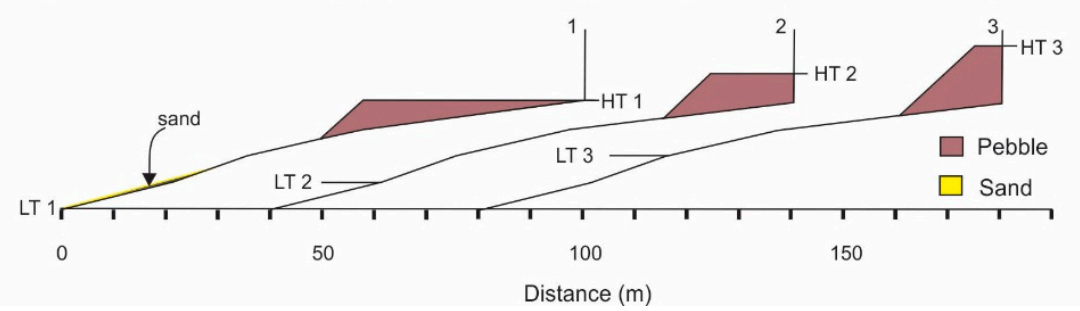

Figure 7. Examples of simulated platform beach responses to rising sea level and their relationship to the shape and gradient of the rock foundation, the amount and grain size of the sediment, and the height of the waves (wave 1 to 5 represents increasing height). LT (1, 2, and 3) and HT (1, 2, and 3) represent, respectively, the mean low water spring and mean high water spring tidal levels for present sea level and two higher sea levels equal to $1 / 4$ and $1 / 2$ of the tidal range above today [40].

\section{Inheritance}

Rock coasts often retain morphological and sedimentary vestiges of former climates and sea level [74-76]. Because of the lack of dateable deposits and uncertainties over the application and interpretation of cosmogenic nuclide analysis [77], it is difficult to determine whether, or to what degree, a coastal element, such as a shore platform, has been inherited from a period, or periods, when sea level was similar to today's (Figure 1). Few models have considered the possible role of inheritance on hard rock coasts although, based on the degree of profile change between consecutive interglacials, 
Trenhaile $[30,31]$ opined that it was important in the development of submarine shelves and intertidal shore platforms during the middle and late Quaternary (Figure 2). Modelling has further suggested that contemporary shore platforms in some places, including in much of the Southern Hemisphere, were partly inherited from the mid-Holocene, when sea level exceeded its present elevation by up to several meters [35].

\section{Modelling Constraints and Limitations}

Although models have provided important insights into modes of coastal development, they cannot replicate natural conditions. For example, while efforts to record wave transition across sloping and subhorizontal shore platforms facilitate better modelling [78-80], it is extremely difficult to convert energy dissipation rates into corresponding rates of rock breakdown. Japanese workers have developed models that relate rates of cliff recession to a variety of factors, including wave height at the cliff foot, compressive and impact strength of the rocks, and longitudinal sound-wave velocity in the rock body [81-83]. Nevertheless, attempts to measure and quantify the driving and resisting forces that determine rates of cliff erosion are confounded by the myriad factors that operate on inherently complex rock coasts. They include, in addition to primary environmental elements, such as rock type, climate, wave regime, and tidal type and range: bores breaking prematurely against upstanding strata in the surf and swash zones; breaker characteristics and stresses; the generation of shock pressures by breaking waves; the gradient of the bottom; rock strength (hardness), bed thickness, and the dip and strike of the rocks in relation to the incoming waves and to the orientation of the cliff face; the amount, grain size, location, and mobility of beach sediment and erosional debris under variable wave and tidal conditions; the susceptibility of the rocks to various types of weathering and bioerosion; the effect of multiple sea level oscillations that differ in amplitude and wavelength; and tectonic and isostatic changes in the elevation of the land. A further uncertainty over the relationship between the driving and resisting forces is concerned with the degree to which erosion occurs as a result of one or perhaps a few storms generating stresses that are well above the threshold resistance of the rocks, or the accumulating effect of multiple, lower stress events that contribute, along with weathering, to a gradual reduction in the resistance threshold [77].To accommodate process uncertainty, several recent studies, albeit largely concerned with soft rock coasts, have applied Monte Carlo simulations and statistical analyses, to model output $[69,84,85]$.

Modellers must be cognizant of a number of important factors:

a) Tidal variations, including the tidal range and the tidal type, control: the way that wave energy is dissipated in the vertical plane; weathering type and efficacy related to the amount of time that rocks are exposed to the air and immersed in salt water; and the distribution and activities of biological agents [4]. Tidal influences can be represented by the tidal duration distribution or by inputting actual tidal data, although it would be impractical to use the latter option over very long, evolutionary-scale periods.

b) Tidal data alone does not adequately represent the distribution of wave energy in the intertidal zone. This is because the largest and most effective waves crossing sloping shore platforms are tidally modulated $[79,80,86]$. The highest waves also operate under storm surge conditions when the tidal level can be elevated, by up to several metres, by wind shear and other weather-induced elements (Figure 3).

c) Soft rock models have often been based on semi-empirical equations derived from the consolidated till coasts of the lower Great Lakes of North America. These equations are site specific and emphasize the erosional effect of wave-generated bottom currents on profile development. They are inappropriate for hard rock coasts because: bottom currents are generally considered to be too weak to be effective in these environments; and erosion is dominated by processes operating around the still water level.

d) Models used to predict the effect of rising sea level and possibly increased storminess in sediment-rich areas must consider changes on beach morphology and volume, and consequently 
such factors as the degree of cliff exposure and whether beach material is protecting or abrading rock surfaces. The underlying assumptions of the Bruun Rule are rarely satisfied on hard rock coasts and should not be used to represent the effect of sea level change on beaches with rigid foundations.

e) Most models have been concerned exclusively with wave-generated backwearing, but they also need to incorporate the effect of weathering and other factors that operate primarily in the vertical plane.

f) It is possible that cryogenic weathering, involving physico-chemical processes that operated during glacial periods, when sea level was much lower than today, played important roles in the development of rock coasts in mid- to high latitudes [48,87,88], pp. 305-308. Therefore, rates of coastal development may have varied considerably in the past, due to the effect of the changing climate on erosional processes and efficacies.

g) The increasing computational and numerical sophistication of rock coast models must not mask a commensurate growth in model assumptions or obfuscate the continuing lack of reliable information on erosion rates and processes. The lack of reliable field data is a crucial problem which has hindered model development and limited their predictive capabilities, particularly in wave-dominated environments. For example, while we have some data on rates of downwearing by weathering and occasionally by abrasion [89-91], we have almost no comparable data on the temporally episodic and spatially sporadic dislodgment of larger rock fragments by wave quarrying [77,92-94].

h) Model calibration is hampered by the lack of comparable, long-term field data and by limited numerical modelling of actual field morphology. Consequently, only limited verification is possible, usually by reference to contemporary erosion rates and morphology in the field. The ability of models to simulate contemporary conditions could be an expression of equifinality, however, concealing the occurrence of marked disparities in the past and their likely existence in the future.

\section{Conclusions}

Despite the inevitable presence of unknown coefficients, rock coast models provide a useful means to investigate relationships between various formative influences, although the lack of reliable, long-term field data imposes important constraints. We lack information on rates of erosion by various mechanical, chemical, and biological processes and how their efficacy varies spatially and temporally in the sub- to supratidal zones. More specifically, while micro-erosion meters and other techniques have provided useful data on abrasion and weathering, we have almost no comparable information on wave quarrying. Modelling is also hindered by the frequent lack of dateable deposits and problems with the use of cosmogenic nuclide analysis in many areas, with the result that workers are unsure of the role of inheritance and equilibrium in long-term coastal development. Significant advances in coastal modelling in the future therefore depend in part on parallel advances in the identification and measurement of erosional processes in different environments, and in determining the age of possibly inherited coastal elements.

Funding: This research received no external funding.

Conflicts of Interest: The authors declare no conflict of interest.

\section{References}

1. Trenhaile, A.S. The Geomorphology of Rock Coasts, 1st ed.; Clarendon Press: Oxford, UK, 1987.

2. Sunamura, T. Geomorphology of Rocky Coasts, 1st ed.; Wiley: New York, NY, USA, 1992.

3. Kennedy, D.M.; Stephenson, W.J.; Naylor, L.A. (Eds.) Rock Coast Geomorphology: A Global Synthesis, 1st ed.; Geological Society Books: London, UK, 2014. 
4. Trenhaile, A.S. Modeling shore platforms: Present status and future developments. In Advances in Coastal Modeling, 1st ed.; Lakhan, V.C., Ed.; Elsevier: Amsterdam, The Netherlands, 2003; pp. 393-409.

5. Stephenson, W.J.; Dickson, M.E.; Trenhaile, A.S. Rock coasts. In Treatise on Geomorphology, 1st ed.; Shroder, J.F., Ed.; Academic Press: San Diego, CA, USA, 2013; Volume 10, pp. 289-307.

6. Lee, E.M.; Hall, J.W.; Meadowcroft, I.C. Coastal cliff recession: The use of probabilistic prediction methods. Geomorphology 2001, 40, 253-269. [CrossRef]

7. Hapke, C.; Plant, N. Predicting coastal cliff erosion using a Bayesian probabilistic model. Mar. Geol. 2010, 278, 140-149. [CrossRef]

8. Vann Jones, E.C.; Rosser, N.J.; Brain, M.J. Alongshore variability in wave energy transfer to coastal cliffs. Geomorphology 2018, 322, 1-14. [CrossRef]

9. Ramsey, A.C. On the denudation of south Wales and the adjacent counties of England. Mem. Geol. Soc. Great Br. 1846, 1, 297-335.

10. Green, A.H. Physical Geology, 2nd ed.; Daldy, Isbister, \& Co.: London, UK, 1877.

11. Geikie, T.N. Textbook of Geology, 4th ed.; Macmillan and Co.: London, UK, 1903; Volume 1.

12. Johnson, D.W. Shore Processes and Shoreline Development, 1st ed.; Wiley: New York, NY, USA, 1919.

13. Davis, W.M. Plains of marine and subaerial denudation. Geol. Soc. Am. Bull. 1896, 7, 377-398. [CrossRef]

14. Fenneman, N.M. Development of the sub-aqueous shore terrace. J. Geol. 1902, 10, 1-32. [CrossRef]

15. Challinor, J. A principle in coastal geomorphology. Geography 1949, 34, 212-215.

16. Edwards, A.B. Storm wave platforms. J. Geomorph. 1941, 4, 223-236.

17. Bird, E.C.F. Coasts, 1st ed.; Australian National University Press: Canberra, Australia, 1968.

18. Trenhaile, A.S. The shore platforms of the Vale of Glamorgan, Wales. Trans. Inst. Br. Geogr. 1972, 56, 127-144. [CrossRef]

19. Focke, J.W. Limestone cliff morphology on Curacao (Netherlands Antilles), with special attention to the origin of notches and vermetid/coralline algal surf benches (corniches, trottoirs). Z. Geomorphol. 1978, 22, 329-349.

20. Sanders, N.K. Wave tank experiments on the erosion of rocky coasts. Proc. R. Soc. Tasman. 1968, 102, 11-16.

21. Sunamura, T. Coastal cliff erosion due to waves-Field investigations and laboratory experiments. J. Faculty Eng. Univ. Tokyo 1973, 32, 1-86.

22. Sunamura, T. A laboratory study of wave-cut platform formation. J. Geol. 1975, 83, 389-397. [CrossRef]

23. Flemming, N.C. Form and relation to present sea level of Pleistocene marine erosion features. J. Geol. 1965, 73, 799-811. [CrossRef]

24. Scheidegger, A.E. Theoretical Geomorphology, 1st ed.; Springer-Verlag: New York, NY, USA, 1970.

25. Sunamura, T. A relationship between wave-induced cliff erosion and erosive force of wave. J. Geol. 1977, 85, 613-618. [CrossRef]

26. Sunamura, T.A. mathematical model of submarine platform development. Math. Geol. 1978, 10, 53-58. [CrossRef]

27. Sunamura, T.A. model of the development of continental shelves having erosional origin. Geol. Soc. Am. Bull. 1978, 89, 504-510. [CrossRef]

28. Robinson, L.A. Marine erosive processes at the cliff foot. Mar. Geol. 1977, 23, 257-271. [CrossRef]

29. Trenhaile, A.S. Modeling the development of wave-cut shore platforms. Mar. Geol. 2000, 166, $163-178$. [CrossRef]

30. Trenhaile, A.S. Modeling the Quaternary evolution of shore platforms and erosional continental shelves. Earth Surf. Proc. Landf. 2001, 26, 1103-1128. [CrossRef]

31. Trenhaile, A.S. Modelling the effect of Pliocene-Quaternary changes in sea level on stable and tectonically active land masses. Earth Surf. Proc. Landf. 2014, 39, 1221-1235. [CrossRef]

32. Trenhaile, A.S. Modeling the development of sloping marine terraces on tectonically mobile rock coasts. Mar. Geol. 2002, 185, 341-361. [CrossRef]

33. Quartau, R.; Trenhaile, A.S.; Mitchell, N.C.; Tempera, F. Development of volcanic insular shelves: Insights from observations and modelling of Faial Island in the Azores Archipelago. Mar. Geol. 2010, 275, 66-83. [CrossRef]

34. Quartau, R.; Trenhaile, A.S.; Ramalho, R.S.; Mitchell, N.C. The role of subsidence in shelf widening around ocean island volcanoes: Insights from observed morphology and modeling. Earth Plan. Sci. Lett. 2018, 498, 408-417. [CrossRef] 
35. Trenhaile, A.S. The effect of Holocene changes in relative sea level on the morphology of rocky coasts. Geomorphology 2010, 114, 30-41. [CrossRef]

36. Thébaudeau, B.; Trenhaile, A.S.; Edwards, R.J. Modelling the development of rocky shoreline profiles along the northern coast of Ireland. Geomorphology 2013, 203, 66-78. [CrossRef]

37. Matsumoto, H.; Dickson, M.E.; Kench, P.S. An exploratory numerical model of rocky shore profile evolution. Geomorphology 2016, 268, 98-109. [CrossRef]

38. Trenhaile, A.S. Rocky coasts-Their role as depositional environments. Earth-Sci. Rev. 2016, 159, 1-13. [CrossRef]

39. Trenhaile, A.S. Modeling the accumulation and dynamics of beaches on shore platforms. Mar. Geol. 2004, 206, 55-72. [CrossRef]

40. Trenhaile, A.S. Modelling the effect of rising sea level on beaches with resistant foundations. Mar. Geol. 2018, 395, 1-13. [CrossRef]

41. Trenhaile, A.S. Modeling the effect of waves, weathering and beach development on shore platform development. Earth Surf. Proc. Landf. 2005, 30, 613-634. [CrossRef]

42. Trenhaile, A.S. Modeling the effect of weathering on the evolution and morphology of shore platforms. J. Coast. Res. 2001, 17, 398-406.

43. Trenhaile, A.S. The development of subhorizontal shore platforms in microtidal environments. Z. Geomorphol. 2008, 52, 105-124. [CrossRef]

44. Trenhaile, A.S. Modeling the role of weathering on shore platform development. Geomorphology 2008, 94, 24-39. [CrossRef]

45. Trenhaile, A.S. Modeling the effect of tidal wetting and drying on shore platform development. J. Coast. Res. 2004, 20, 1049-1060. [CrossRef]

46. Trenhaile, A.S.; Porter, N.J. Can shore platforms be produced solely by weathering processes? Mar. Geol. 2007, 241, 79-92. [CrossRef]

47. Matsumoto, H.; Dickson, M.E.; Kench, P.S. Modelling the relative dominance of wave erosion and weathering processes in shore platform development in micro- to mega-tidal settings. Earth Surf. Proc. Landf. 2018, 43, 2642-2653. [CrossRef]

48. Matthews, J.A.; Dawson, A.G.; Shakesby, R.A. Lake shoreline development, frost weathering and rock platform erosion in an alpine periglacial environment, Jotunheimen, southern Norway. Boreas 1986, 15, 33-50. [CrossRef]

49. Trenhaile, A.S. Sea level oscillations and the development of rock coasts. In Applications in Coastal Modeling, 1st ed.; Lakhan, V.C., Trenhaile, A.S., Eds.; Elsevier: Amsterdam, The Netherlands, 1989; pp. 271-295.

50. Trenhaile, A.S. Modelling tidal notch formation by wetting and drying and salt weathering. Geomorphology 2014, 224, 139-151. [CrossRef]

51. Trenhaile, A.S. Modelling coastal notch morphology and developmental history in the Mediterranean. GeoResJ 2016, 9-12, 77-90. [CrossRef]

52. Kline, S.W.; Adams, P.N.; Limber, P.W. The unsteady nature of sea cliff retreat due to mechanical abrasion, failure and comminution feedbacks. Geomorphology 2014, 219, 53-67. [CrossRef]

53. Trenhaile, A.S. The width of shore platforms; a theoretical approach. Geogr. Ann. 1983, 65A, 147-158. [CrossRef]

54. Muir-Wood, A.M. Engineering aspects of coastal landslides. Proc. Inst. Civ. Eng. 1971, 50, 257-276. [CrossRef]

55. Komar, P.D. Beach Processes and Sedimentation, 1st ed.; Prentice Hall: Englewood Cliffs, NJ, USA, 1976.

56. Limber, P.W.; Murray, A.B.; Adams, P.N.; Goldstein, E.B. Unraveling the dynamics that scale cross-shore headland relief on rocky coastlines: 1. Model development. J. Geophys. Res. (Earth Sci.) 2014, 119, 1-20. [CrossRef]

57. Limber, P.W.; Murray, A.B. Unraveling the dynamics that scale cross-shore headland relief on rocky coastlines: 2. Model predictions and initial tests. J. Geophys. Res. (Earth Sci.) 2014, 119, 874-891. [CrossRef]

58. Limber, P.W.; Murray, A.B. Sea stack formation and the role of abrasion on beach-mantled headlands. Earth Surf. Proc. Landf. 2015, 40, 559-568. [CrossRef]

59. Shepard, F.P.; Grant, U.S. Wave erosion along the southern California coast. Geol. Soc. Am. Bull. 1947, 58, 919-926.

60. Scheidegger, A.E. Marine terraces. Pure Appl. Geophys. 1962, 52, 69-82. [CrossRef] 
61. King, C.A.M. Some problems concerning marine planation and the formation of erosion surfaces. Trans. Inst. Br. Geogr. 1963, 33, 29-43. [CrossRef]

62. Trenhaile, A.S.; Byrne, M.L. A theoretical investigation of rock coasts, with particular reference to shore platforms. Geogr. Ann. 1986, 68A, 1-14. [CrossRef]

63. Cinque, A.; De Pippo, T.; Romano, P. Coastal slope terracing and relative sea-level changes: Deductions based on computer simulations. Earth Surf. Proc.Land. 1995, 20, 87-103. [CrossRef]

64. Anderson, R.S.; Densmore, A.L.; Ellis, M.A. The generation and degradation of marine terraces. Basin Res. 1999, 11, 7-19. [CrossRef]

65. Trenhaile, A.S. Modeling the effect of late Quaternary interglacial sea levels on wave-cut shore platforms. Mar. Geol. 2001, 172, 205-223. [CrossRef]

66. Trenhaile, A.S. Predicting the response of hard and soft rock coasts to changes in sea level and wave height. Climat. Chang. 2011, 109, 599-615. [CrossRef]

67. Young, A.P.; Flick, R.E.; O’Reilly, W.C.; Chadwick, D.B.; Crampton, W.C.; Helly, J.J. Estimating cliff retreat in southern California considering sea level rise using a sand balance approach. Mar. Geol. 2014, 348, 15-26. [CrossRef]

68. Bruun, P. The Bruun Rule of erosion by sea-level rise: A discussion of large-scale two- and three-dimensional usages. J. Coast. Res. 1988, 4, 627-648.

69. Limber, P.W.; Barnard, P.L.; Vitousek, S.; Erikson, L.H. A model ensemble for projecting multidecadal coastal cliff retreat during the 21st century. J. Geophys. Res. (Earth Sci.) 2018, 123, 1566-1589. [CrossRef]

70. Taborda, R.; Ribeiro, M.A. A simple model to estimate the impact of sea-level rise on platform beaches. Geomorphology 2015, 234, 204-210. [CrossRef]

71. Sunamura, T. Feedback relationship in wave erosion of laboratory rocky coast. J. Geol. 1976, 84, 427-437. [CrossRef]

72. Trenhaile, A.S.; Layzell, M.G.J. Shore platforms morphology and the tidal duration factor. Trans. Inst. Br. Geogr. 1981, 6, 82-102. [CrossRef]

73. Dickson, M.E.; Ogawa, H.; Kench, P.S.; Hutchinson, A. Sea-cliff retreat and shore platform widening: Steady-state equilibrium? Earth Surf. Proc. Landf. 2013, 38, 1046-1048. [CrossRef]

74. Young, R.W.; Bryant, E.A. Coastal rock platforms and ramps of Pleistocene and Tertiary age in southern New South Wales, Australia. Z. Geomorphol. 1993, 37, 257-272.

75. Stone, J.; Lambeck, K.; Fifield, L.K.; Evans, J.M.; Cresswell, R.G. A Lateglacial age for the Main Rock Platform, western Scotland. Geology 1996, 24, 707-710. [CrossRef]

76. Trenhaile, A.S.; Pérez Alberti, A.; Martınez Cortizas, A.; Costa Casais, M.; Blanco Chao, R. Rock coast inheritance: An example from Galicia, northwestern Spain. Earth Surf. Proc. Landf. 1999, 24, 605-621. [CrossRef]

77. Trenhaile, A.S. Shore platform erosion and evolution: Implications for cosmogenic nuclide analysis. Mar. Geol. 2018, 403, 80-92. [CrossRef]

78. Ogawa, H.; Dickson, M.E.; Kench, P.S. Hydrodynamic constraints and storm wave characteristics on a sub-horizontal shore platform. Earth Surf. Proc. Landf. 2015, 40, 65-77. [CrossRef]

79. Poate, T.; Masselink, G.; Austin, M.; Dickson, M.; McCall, R. The role of bed roughness in wave transformation across sloping rock shore platforms. J. Geophys. Res. (Earth Surf.) 2018, 123, 97-123. [CrossRef]

80. Stephenson, W.J.; Naylor, L.A.; Smith, H.; Chen, B.; Braynes, R.P. Wave transformations across a cliff-backed macrotidal sloping shore platform under low to moderate energy conditions. Earth Surf. Proc. Landf. 2018, 43, 298-311. [CrossRef]

81. Horikawa, K.; Sunamura, T. A study on erosion of coastal cliffs by using aerial photographs. Coast. Eng. Jpn. 1967, 10, 67-83. [CrossRef]

82. Sunamura, T. Rocky coast processes: With special reference to the recession of soft rock cliffs. Proc. Jpn. Acad. Ser. 2015, 91, 481-500. [CrossRef]

83. Tsujimoto, H. Dynamic conditions for shore platform initiation. Sci. Rep. Inst. Geosci. Univ. Tsukuba 1987, A8, 45-93.

84. Barkwith, A.; Thomas, C.W.; Limber, P.W.; Ellis, M.A.; Murray, A.B. Coastal vulnerability of a pinned, soft-cliff coastline - Part I: Assessing the natural sensitivity to wave climate. Earth Surf. Dyn. 2014, 5, 67-84. [CrossRef] 
85. Hurst, M.D.; Rood, D.H.; Ellis, M.A.; Anderson, R.S.; Dornbusch, U. Recent acceleration in coastal cliff retreat rates on the south coast of Great Britain. Proc. Natl. Acad. Sci. USA 2016, 113, 13336-13341. [CrossRef] [PubMed]

86. Trenhaile, A.S.; Kanyaya, J.I. The role of wave erosion on sloping and horizontal shore platforms in macroand mesotidal environments. J. Coast. Res. 2007, 23, 298-309. [CrossRef]

87. Dawson, A.G. Shore erosion by frost: An example from the Scottish late glacial. In Studies in the Late Glacial of North West Europe, 1st ed.; Lowe, J.J., Gray, J.M., Robinson, J.E., Eds.; Pergamon: Oxford, UK, 1980; pp. 45-53.

88. Trenhaile, A.S. Coastal Dynamics and Landforms, 1st ed.; Oxford University Press: Oxford, UK, 1997.

89. Stephenson, W.J.; Kirk, R.M.; Hemmingsen, S.A.; Hemmingsen, M.A. Decadal scale micro erosion rates on shore platforms. Geomorphology 2010, 114, 22-29. [CrossRef]

90. Stephenson, W.J.; Kirk, R.M.; Kennedy, D.M.; Finlayson, B.L.; Chen, Z. Long term shore platform surface lowering rates: Revisiting Gill and Lang after 32 years. Mar. Geol. 2012, 299-302, 90-95. [CrossRef]

91. Trenhaile, A.S.; Porter, N.J. Shore platform downwearing in eastern Canada; A 9-14 year micro-erosion meter record. Geomorphology 2018, 311, 90-102. [CrossRef]

92. Naylor, L.A.; Stephenson, W.J. On the role of discontinuities in mediating shore platform erosion. Geomorphology 2010, 114, 89-100. [CrossRef]

93. Cruslock, E.M.; Naylor, L.A.; Foote, Y.L.; Swantesson, J.O.H. Geomorphologic equifinality: A comparison between shore platforms in Höga Kusten and Fårö, Sweden and the Vale of Glamorgan, South Wales, UK. Geomorphology 2010, 114, 78-88. [CrossRef]

94. Regard, V.; Dewez, T.; Cnudde, C.; Hourizadeh, N. Coastal chalk platform erosion modulated by step erosion and debris shielding: Example from Normandy and Picardy (northern France). Proceedings 12th International Coastal Symposium (Plymouth, England). J. Coast. Res. 2013, 65, 1692-1697. [CrossRef]

(C) 2019 by the author. Licensee MDPI, Basel, Switzerland. This article is an open access article distributed under the terms and conditions of the Creative Commons Attribution (CC BY) license (http:/ / creativecommons.org/licenses/by/4.0/). 